\section{Stereoselective Rhodium-Catalyzed Arylzincation of Terminal Allenes}

Metal-Mediated Synthesis

Key words

terminal allenes

three-component reaction

arylzincation

rhodium

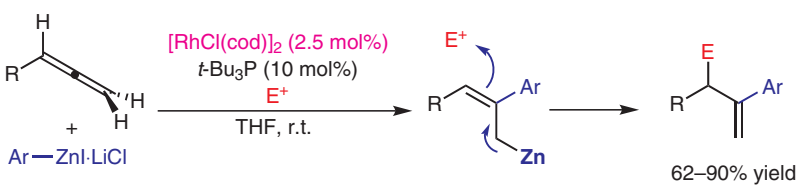

Selected examples:<smiles>C=C(c1ccccc1)C(CCCC)C(C)=O</smiles><smiles>C=C(c1ccccc1)C(O)C(O)(CC)CC</smiles><smiles>C=C(c1ccc(C(=O)OCC)cc1)C(CC)C(C)=O</smiles><smiles>C=C(c1cccc(C(F)(F)F)c1)C(CCCCC)C(C)=O</smiles>

$90 \%$ yield

$$
\begin{gathered}
79 \% \text { yield } \\
E^{+}=3-p e n t a n o n
\end{gathered}
$$

$62 \%$ yield

$81 \%$ yield<smiles>C=C(c1ccc(Br)cc1)[C@H](C)C(Nc1ccccc1)c1ccc(Br)cc1</smiles>

$83 \%$ yield $(\mathrm{dr}>99: 1)$ $\mathrm{E}^{+}=4-\mathrm{MeOC}_{6} \mathrm{H}_{4}=\mathrm{NPh}$
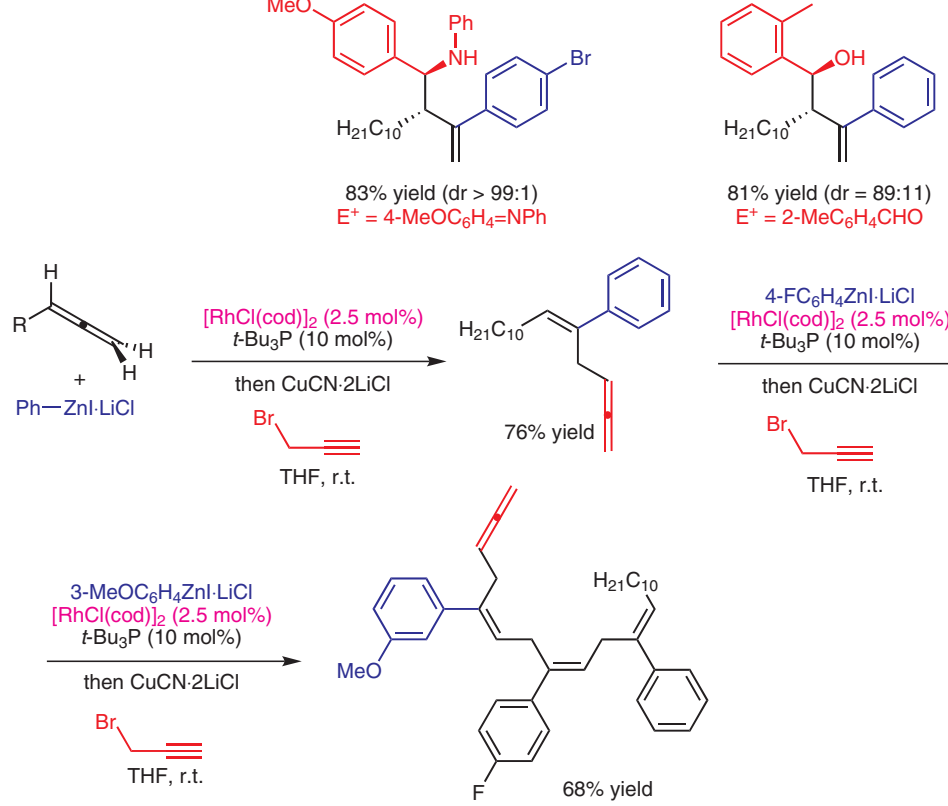

$81 \%$ yield $(\mathrm{dr}=89: 11)$ $\mathrm{E}^{+}=2-\mathrm{MeC}_{6} \mathrm{H}_{4} \mathrm{CHO}$
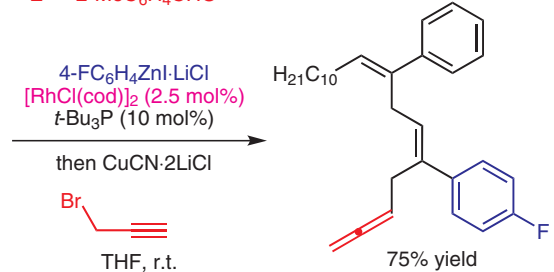

Significance: A novel efficient rhodium-catalyzed multicomponent reaction using an arylzinc iodide, a monosubstituted allene and an electrophile $\left(\mathrm{E}^{+}\right)$ is reported. With acetonitrile and imines or aldehydes as electrophiles the use of Barbier-type conditions furnished the best yields. The reaction is highly diastereoselective, and thus allowed the synthesis of a stereodefined skipped polyene.
Comment: Multicomponents allow an easy onepot access to molecular complexity. Multicomponent reactions involving allenes have recently attracted increased attention due to their efficiency. The high stereoselectivity of this reaction makes it a very valuable tool for modern synthesis.

Review: S. Ma Chem. Rev. 2005, 105, 28292871.

SYNFACTS Contributors: Paul Knochel, Tobias Thaler 